\title{
Metallothionein responses of mangrove crab, Sesarma huzardi, exposed to oily drill cuttings
}

\author{
M.U. ANAGBOSO ${ }^{1}$, L.O. CHUKWU ${ }^{1 *}$ and M. IGWO-EZIKPE ${ }^{2}$ \\ ${ }^{1}$ Aquatic Toxicology and Ecophysiology Laboratory, Department of Marine Sciences, University of Lagos, \\ Akoka Yaba, Lagos, Nigeria. \\ ${ }^{2}$ Department of Biochemistry, University of Lagos, Nigeria. \\ * Corresponding author, E-mail: obinnalcunilag@yahoo.com
}

\begin{abstract}
The call to incorporate biomarker studies in biomonitoring and ecotoxicological programmes has gained immense support in recent times prompting studies at the sub organismal levels with the aim of developing protocols that will aid to safeguard the whole ecosystem from pollution effect. Metallothioneins (MTs) are low molecular weight, cysteine rich proteins that are involved in protecting the cell during stress. Mangrove crabs, Sesarma huzardi, were exposed to $0.0196 \mathrm{~h} \mathrm{LC}_{50}$ and $0.196 \mathrm{~h} \mathrm{LC}_{50}$ drill cuttings concentrations and the MT levels monitored over a period of 16 days. MT was significantly elevated in drill cuttings exposed crabs but not in the control group. The implications of the finding and the possible inclusion of MT in the biomonitoring of drill cuttings impacted areas are discussed.

(c) 2009 International Formulae Group. All rights reserved.
\end{abstract}

Keywords: Biomarker Metallothionein, Mangrove Crab, Drill Cuttings.

\section{INTRODUCTION}

Aquatic systems are subject to various natural and anthropogenic induced stressors, the impacts of which may manifest at different levels of biological organisations (Depledge and Hopkin, 1995). Perkin (1979) suggested the use of sublethal tests to study the responses of organisms including reproductive potential to low level exposure to environmental wastes as acute toxicity test may actually be a poor indicator of chronic exposure in some organisms (Newton and McKenzie, 1998). In addition some researchers have proposed the use of biological indicators to complement traditional methods of pollution monitoring (Handy and Depledge 1999; Damien et al., 2004; Moore et al., 2004) since it is believed that sublethal pollutant induced effects in biological system will first occur at biochemical and subcellular level before they manifest at higher biological level (Galloway et al., 2002). This is more so as aquatic organisms are often exposed to chronic levels of chemicals in their environment (Handy et al., 2003), which commonly occur in complex forms. Issues have been raised on the suitability of controlled laboratory studies of pollutant effects because such studies exhibit low levels of biological and environmental realism, excluding significant inter-species and ecosystem-level interactions. However, while field observations are more useful, they are not easily standardised, are expensive and time consuming. For these reasons laboratory studies especially using single species have continued to be employed in studying pollutant effects in laboratory exposed organisms.

Metallothioneins (MTs) are cysteine rich, low molecular weight proteins that normally bind with metal ions. They have 
been found in many organisms (Roesijadi, 1992) and are suspected to be ubiquitous. The proteins are believed to protect against some metallic and nonmetallic chemicals (Hamer, 1986; Langston et al., 1989; Roesijadi, 1994; Klaassen and Liu, 1998; Ng and Wang, 2004). Protection against oxidative stress has also been attributed to MT (Pitt et al., 1997; Viarengo et al., 1999). Though additional synthesis of MT is mostly attributed to particular metals, MT induction by other non metal agents such as hormones, environmental factors and many chemicals have been reported in the literature (Ghoshal et al., 1998; Leung et al., 2001; English and Storey, 2003). Overexpression of the protein may therefore be regarded as an adaptive response to environmental stimuli. MT family is believed to be composed of at least four isoforms and Lacorn et al. (2001) have suggested that inclusion of measurement of MT in biomonitoring as have been suggested by several authors will of necessity include the quantification of the different isoforms and their induction patterns. The half life and/or persistence of induction of the protein during exposure to external factor is another issue which need to be addressed if the MT is to be adopted in monitoring exercise (Leung et al., 2001).

One of the main sources of environmental contamination of the marine environment is the exploitation of petroleum and other hydrocarbon products, which produces environmental risks and impacts resulting from not only accidental spills and blowouts, but also from permissible discharges of operational wastes such as drilling muds and drill cutting (Roddie et al., 1999) as it is the case in Nigeria. Drilling muds are essential component of the rotary system used to drill for oil and gas and often coats drill cuttings. They are responsible for toxicity of drill cuttings, which are produced by the grinding action of the drill bit as it penetrates into the earth. There is concern that any adhering mud additive may be toxic, particularly if the cutting are produced during drilling with oil based or synthetic mud (Neff et al., 2000), raising concern regarding their disposal.

Presently in Nigeria, there is paucity of data on biological responses of marine organisms generally when exposed to additional environmental chemicals and on metallothionein induction in particular. This study is therefore a preliminary study on the potential utility of MT in biomonitoring studies of drill cuttings impacted marine areas. Field collected Sesarma huzardi were exposed to oily drill cuttings in the laboratory and at pre-determined intervals, metallothionein levels were monitored in the digestive glands of the crabs. S. huzardi is a common crab found in the mangrove swamps of West Africa including in the oil rich Niger Delta area of Nigeria. The crab serves as an important source of protein to local inhabitants. It is also a significant member of the mangrove community, where the adult crabs feed on mangrove grasses and leaves. The adults also feed on other crabs and are considered opportunity feeders. In water, the crabs are known to feed on algae, while the young crabs serve as food source to fishes.

\section{MATERIALS AND METHODS Animals}

Adult specimens of $S$. huzardi (mangrove crab) (Arthropoda, Crustacean, Decapoda, Grapsidae) were collected from field by hand picking into a holding bucket from the mangrove area adjacent the Lagoon Front section of Lagos lagoon. These were taken to the laboratory and left in holding tanks with a thin layer of sediment serving as substrate and food source to organism, and some water to allow them to acclimatise to laboratory conditions for 72 hours. Thereafter, male crabs were separated from the female crabs and animals of similar length were selected for all bioassays. Lagoon water and sediments were also simultaneously collected from field for use in the bioassay procedure. The sediments were sun dried to standardise moisture content, and subsequently passed through a sieve $(0.25 \mathrm{~mm})$ to obtain uniform substrate particles.

\section{Test chemicals}

The toxicant used during the bioassays is drill cuttings which was collected from Shell Development Petroleum Corporation with physico-chemical properties as shown in Table 1 . The cuttings were coated with the oil based mud used during the drilling process. The drill cutting was relatively alkaline with 
mean $\mathrm{pH}$ value of $9.28 \pm 0.06$ and total hydrocarbon content of $25.14 \pm 0.12 \mu \mathrm{g} / \mathrm{g}$.

\section{General bioassay procedure}

Bioassay tests were carried out using plastic tanks, which measured $45 \mathrm{~cm} \mathrm{X} 30 \mathrm{~cm}$ $\mathrm{X} 20 \mathrm{~cm} .200 \mathrm{~g}$ of sediment was introduced into the experimental tank and lagoon water was used as the diluents for the entire bioassay test conducted. Table 2 gives the physico-chemical properties of the lagoon water used. Sediments were first spread to form a uniform layer in the bioassay container. Thereafter, pre-determined concentrations of drill cuttings were added followed by the addition of 1 liter of water less the volume of the drill cuttings. The contents of the container were then gently mixed to achieve even distribution of cuttings on the sediment before the introduction of test species. This procedure was adopted in all cases of bioassay.

\section{Sublethal toxicity test}

Static renewal method was adopted during exposure period. Test solutions and sediment were renewed on day 4,8 , and 16 . For the series of bioassays, 50 specimens of $S$. huzardi were exposed in two replicates per treatment, i.e. 25 specimen per replicate, including control. The concentrations of drill cuttings used were derived from the $96 \mathrm{hLC}_{50}$ value obtained for the toxicant in a previous study with the organism, and are as follows:

- $81.50 \mathrm{ml} / 1$ (i.e. 0.01 of the $96 \mathrm{hLC}_{50}$ ) plus $918.50 \mathrm{ml}$ lagoon water, $8.15 \mathrm{ml} / \mathrm{l}$

Table 1: Chemical properties of drill cuttings.

\begin{tabular}{lc}
\hline Chemical Parameter & Level Detected (mean \pm standard deviation) \\
\hline $\mathrm{Ba}(\mu \mathrm{g} / \mathrm{g})$ & $0.013 \pm 0.06$ \\
$\mathrm{Na}(\mu \mathrm{g} / \mathrm{g})$ & $0.182 \pm 0.06$ \\
$\mathrm{~K}(\mu \mathrm{g} / \mathrm{g})$ & $0.142 \pm 0.25$ \\
$\mathrm{Fe}(\mu \mathrm{g} / \mathrm{g})$ & $2.581 \pm 0.10$ \\
$\mathrm{Cu}(\mu \mathrm{g} / \mathrm{g})$ & $0.344 \pm 0.00$ \\
$\mathrm{Zn}(\mu \mathrm{g} / \mathrm{g})$ & $1.851 \pm 0.06$ \\
$\mathrm{Cd}(\mu \mathrm{g} / \mathrm{g})$ & $0.002 \pm 0.25$ \\
$\mathrm{Ag}(\mu \mathrm{g} / \mathrm{g})$ & $\mathrm{ND}$ \\
$\mathrm{Pb}(\mu \mathrm{g} / \mathrm{g})$ & $0.015 \pm 0.15$ \\
$\mathrm{~V}(\mu \mathrm{g} / \mathrm{g})$ & $\mathrm{ND}$ \\
$\mathrm{Mn}(\mu \mathrm{g} / \mathrm{g})$ & $0.056 \pm 0.25$ \\
$\mathrm{Total} \mathrm{Hydrocarbon} \mathrm{Content}(\mathrm{THC})(\mu \mathrm{g} / \mathrm{g})$ & $25.14 \pm 0.12$ \\
$\mathrm{Salinity}(\% o)$ & $1.22 \pm 0.10$ \\
$\mathrm{pH}$ & $9.28 \pm 0.06$ \\
\hline
\end{tabular}

Table 2: Chemical characteristics of dilution water used in the bioassay.

\begin{tabular}{lc}
\hline Chemical Parameter & Concentration \\
\hline $\mathrm{pH}$ & 7.32 \\
Total Organic Carbon & $0.04 \mathrm{mg} / \mathrm{l}$ \\
Total Hydrocarbon Content (THC) & $\mathrm{ND}$ \\
Salinity & $8.4 \%$ \\
Iron $(\mathrm{Fe})$ & $1.42 \mathrm{mg} / 1$ \\
Copper $(\mathrm{Cu})$ & $0.65 \mathrm{mg} / 1$ \\
Zinc $(\mathrm{Zn})$ & 11.26 \\
Cadmium $(\mathrm{Cd})$ & 0.005 \\
Silver $(\mathrm{Ag})$ & \\
\hline
\end{tabular}


(i.e. 0.1 of the $96 \mathrm{hLC}_{50}$ ) plus $991.50 \mathrm{ml}$ lagoon water, and

- Control.

\section{Tissue preparation}

For each treatment, 5 specimens of crabs from each replicate making 10 for each treatment were randomly collected from bioassay chambers on day 4, 8, and 16 . Sample collection was also done prior to commencement of sublethal tests in order to obtain the basal level of MT in the crab. The digestive gland was chosen for metallothionein studies and was collected after careful removal of the ventral carapace and the surrounding tissues. The digestive glands for each treatment were then pooled to minimise individual variability. This procedure was adopted for both male and female crabs.

\section{Metallothionein determination}

Metallothionein levels were assessed on the digestive gland homogenates content of the samples by evaluating the sulphyhydryl (SH) residue according to Ellman (1959); Viarengo et al. (1997). The amount of MT was defined assuming a cysteine content of 23. The MT concentrations of 3 replicates for each measurement were calculated using reduced glutathione (GSH) as a standard and expressed as (n mol MT). $\mathrm{g}^{-1}$. Chemicals were obtained from Ikzus Environment, Italy.

\section{Reagent and working solutions preparation} Sulfhydryl reference (reduced glutathione) standard was prepared by adding $0.725 \mathrm{Sol} \mathrm{C}_{2}$ (resuspension buffer Component 2) to a microtube. The reaction buffer ( $\mathrm{sol} \mathrm{D}$ ) was obtained by mixing $200 \mathrm{ml}$ stabilised Ellman's buffer and $3.4 \mathrm{ml}$ concentrated Ellman's reagent and equilibrated at $23{ }^{\circ} \mathrm{C}$. Absolute ethanol was also equilibrated at -20 ${ }^{\circ} \mathrm{C}$. The homogeniting buffer was obtained by adding 1 part of sol B (protease inhibitor) to 99 parts of sol A extraction buffer. The resuspension buffer was prepared by mixing equal amounts of sol $\mathrm{C}_{1}$ (resuspension buffer, Component 1) and sol $\mathrm{C}_{2}$ (resuspension buffer, Component 2). The blank solution was obtained by mixing $50 \mu \mathrm{l} \mathrm{Sol} \mathrm{C}$ (resuspension buffer, Component 1) and $1.950 \mu \mathrm{l}$ Sol D (reaction buffer).
Procedure for the extraction and evaluation of metallothionein content

A quantity of $0.5 \mathrm{~g}$ of tissue was homogenised at $0-4{ }^{\circ} \mathrm{C}$ using the already prepared homogenating buffer and centrifuged at $30,000 \mathrm{~g}$ at $4{ }^{\circ} \mathrm{C}$ for $20 \mathrm{~min}$. The protein content was then determined from the supernatant by means of Bradford assay. The supernatant was collected in a $2 \mathrm{ml}$ tube. 1.5 $\mathrm{ml}$ of cold absolute ethanol was added to the tube and incubated at $-20{ }^{\circ} \mathrm{C}$ for $30-60 \mathrm{~min}$. The mixture was then centrifuge at 12$16,000 \mathrm{~g}$ at $4{ }^{\circ} \mathrm{C}$ for 5 minutes. $1.95 \mathrm{ml}$ of the previously prepared reaction buffer, which was equilibrated at room temperature (RT) was then added. The resulting mixture was mixed, incubated for 2 minutes at room temperature and then centrifuge at 12$16,000 \mathrm{~g}$. Absorbance was thereafter read at $412 \mathrm{~nm}$ against the blank solution, and a standard curve was obtained by plotting absorbance against the concentration. Absorbance was also read for samples at 412 nm. To calculate metallothionein concentration, the $\mathrm{ABS}^{\mathrm{MT}}{ }_{412}$ value of sample was interpolated over the standard curve to obtain the concentration (nmol) of sulfhydryl groups, i.e. cysteine residues (nmol $\mathrm{Cys}^{\mathrm{MT}}$ ), due to metallothionein present in the sample. To obtain the concentration of metallothionein (nmol MT) per gram of tissue, the following was applied:

$(\mathrm{nmol} \mathrm{MT}) \mathrm{g}^{-1}=\quad\left(\mathrm{nmol} \mathrm{Cys}^{\mathrm{MT}}\right)$

where: $0.1 \mathrm{~g}$ is the amount of tissue equivalent to $0.3 \mathrm{ml}$ of supernatant subjected to precipitation.

$\mathrm{n}^{\text {ocys }}$ is the number of cysteine residue present in the investigated metallothionein.

\section{Statistical analysis}

One-way analysis of variance (ANOVA) was used to compare the means of results obtained, and where a significant difference $(\mathrm{P}<0.05)$ was obtained, Duncan test was used to detect the source of difference. Unpaired Sample t-test was also used to test for significant difference between means of MT results obtained between male and female $S$. huzardi. All statistics were first determined at $\mathrm{P}<0.05$ significant level, and where high significant difference was 
observed, a significant level of $\mathrm{P}<0.01$ or $\mathrm{P}<$ 0.001 is applied.

\section{RESULTS}

\section{Metallothionein induction in $S$. huzardi}

At the start of the experiment, the mean background $0.1913 \mathrm{nmol}^{\mathrm{MT}} \mathrm{g}^{-1}$. MT level of male was higher than the $0.1783 \mathrm{nmol}^{\mathrm{MT}} \mathrm{g}^{-1}$ observed in female $S$. huzardi. The concentration of MT in male $S$. huzardi ranged from $0.1913 \mathrm{nmol}^{\mathrm{MT}} \mathrm{g}^{-1}$ to $0.2042 \mathrm{nmol}^{\mathrm{MT}} \mathrm{g}^{-1}\left(\right.$ mean $\left.=0.1967 \mathrm{nmol}^{\mathrm{MT}} \mathrm{g}^{-1}\right)$ in control organisms, $0.1913 \mathrm{nmol}^{\mathrm{MT}} \mathrm{g}^{-1}$ to $4.30 \mathrm{nmol}^{\mathrm{MT}} \mathrm{g}^{-1}\left(\right.$ mean $\left.=2.5206 \mathrm{nmol}^{\mathrm{MT}} \mathrm{g}^{-1}\right)$ in organisms exposed to $8.15 \mathrm{ml} / 1$, and 0.1913 $\mathrm{nmol}^{\mathrm{MT}} \mathrm{g}^{-1}$ to $3.8696 \mathrm{nmol}^{\mathrm{MT}} \mathrm{g}^{-1}$ (mean = $\left.2.6457 \mathrm{nmol}^{\mathrm{MT}} \mathrm{g}^{-1} 1\right)$ in $81.5 \mathrm{ml} / 1$ exposed organisms (Table 3 ). ANOVA revealed that there was a significant difference $(\mathrm{P}<0.05)$ in MT concentration in control male $S$. huzardi, post hoc using Duncan test showed the source of variation to have occurred on day 4 , which was significantly different from the values observed on day 0 , day 8 and day 16 while there was no statistical difference $(\mathrm{P}>0.05)$ in MT concentrations on day 0,8 and 16 . Statistical differences $(\mathrm{P}<0.001)$ were also observed in the two treatments exposed to drill cuttings. Post hoc test with Duncan revealed that the differences observed in the drill cuttings exposed groups were significant on all sampling days $(\mathrm{P}<0.001)$. Exposure to drill cuttings has an effect on MT induction in male crab as indicated by the statistical difference among control crabs and crabs exposed to drill cuttings $(\mathrm{P}<0.001)$.

In female $S$. huzardi, MT concentrations ranged from $0.1739 \mathrm{nmol}^{\mathrm{MT}} \mathrm{g}^{-1}$ to $0.1783 \mathrm{nmol}^{\mathrm{MT}} \mathrm{g}^{-1}$ (mean $=0.1761 \mathrm{nmol}^{\mathrm{MT}} \mathrm{g}^{-}$ 1) in control organisms, $0.1783 \mathrm{nmol}^{\mathrm{MT}} \mathrm{g}^{-1}$ to $3.6522 \mathrm{nmol}^{\mathrm{MT}} \mathrm{g}^{-1}\left(\right.$ mean $\left.=2.3707 \mathrm{nmol}^{\mathrm{MT}} \mathrm{g}^{-1} 1\right)$ in organisms exposed to $8.15 \mathrm{ml} / 1$, and 0.1783 $\mathrm{nmol}^{\mathrm{MT}} \mathrm{g}^{-1}$ to $3.2609 \mathrm{nmol}^{\mathrm{MT}} \mathrm{g}^{-1}$ (mean = $2.1685 \mathrm{nmol}^{\mathrm{MT}} \mathrm{g}^{-1}$ ) in $81.5 \mathrm{ml} / \mathrm{l}$ exposed organisms (Table 3). ANOVA showed that there was no significant difference $(P>0.05)$ in the control female crabs during the study, while significance differences $(\mathrm{P}<0.001)$ were observed in the two treatments exposed to drill cuttings. Post hoc treatment with Duncan showed that the differences observed in the drill cuttings exposed groups were significant $(\mathrm{P}<0.001)$ on all the sampling days. Test using ANOVA revealed statistical difference $(\mathrm{P}<0.001)$ among control and drill cuttings exposed groups.

In both male and female crabs, the total protein concentrations increased in all treatments including control during the 16 day experiment. A closer study of the results however indicated that in both control groups, the relative concentration of MT to total protein was reducing with increase in exposure time. In drill cuttings exposed treatments on the other hand, MT concentration relative to total proteins increased with time to day 8 , but fell on day 16 (Figures 1 and 2).

\section{DISCUSSION}

The result of the present study revealed that MT level remained relatively stable over the experimental period in control groups of both male and female crabs with the absolute value being higher in male than in female for any treatment group as indicated by the values of cysteine residue during the study. Sex related differences in MT induction was observed in control and in $0.196 \mathrm{hLC}_{50}$ drill cuttings concentration exposed crabs, but not in crabs exposed $0.0196 \mathrm{hLC}_{50}$ drill cuttings concentration. The method of analysis employed allowed the determination of the total protein present and the results revealed that on exposure of $S$. huzardi to drill cuttings, the organism responded by increasing production of proteins, some of which may include enzymes necessary for the synthesis of additional metallothionein. Over time increased production of protein continued, but synthesis of new MT synthesis reached a plateau and then decreased. In control, increased protein production over the study period did not coincide with increased MT induction, thus the enhanced induction of MT in drill cuttings exposed crab may be regarded as a measure of response to stress condition. This conclusion holds true for both male and female $S$. huzardi.

MT is strongly induced by some heavy metals. A concurrent study with the present one revealed no statistical differences in heavy metal $(\mathrm{Zn}, \mathrm{Cu}, \mathrm{Fe})$ concentration among the different treatments. Furthermore Cadmium and Silver which are known to strongly induce MT were below the detectable limit of the method of determination. Two likely sources of variation in the induction 
pattern of MT observed in the crabs are suggested. First, that the observed MT levels were in response to the varying levels of essential metals copper and zinc observed during the study, or second that MT response may be related to physiological factors from lack of food as well as confounding factors arising from confinement. The latter suggestion may be partly rejected on the basis that both control and exposed crabs were similarly treated with respect to feeding though influence of factors such as confinement cannot be totally ruled out (Ghoshal et al., 1998). The former suggestion seems more likely in this case since the introduction of drill cuttings into the

Table 3: Induction of metallothionein in $S$. huzardi on sublethal exposure to drill cuttings.

\begin{tabular}{|c|c|c|c|c|c|}
\hline $\begin{array}{l}\text { Incubation } \\
\text { Time (day) }\end{array}$ & $\mathrm{n}^{0} \mathrm{Cys}$ & $\begin{array}{l}\text { wt of tissue } \\
\text { (g) }\end{array}$ & Protein (mg/l) & nmol Cys ${ }^{M T}$ & nmol MT $\mathrm{g}^{-1}$ \\
\hline 0 & 23 & 0.1 & $8.2 \pm 0.10^{\mathrm{d}}$ & $0.44 \pm 0.10^{b}$ & $0.1913 \pm 0.00^{b}$ \\
\hline 4 & 23 & 0.1 & $12.6 \pm 0.10^{\mathrm{c}}$ & $0.47 \pm 0.10^{\mathrm{a}}$ & $0.2043 \pm 0.00^{\mathrm{a}}$ \\
\hline 8 & 23 & 0.1 & $17.5 \pm 0.06^{\mathrm{b}}$ & $0.45 \pm 0.06^{\mathrm{b}}$ & $0.1957 \pm 0.00^{b}$ \\
\hline 16 & 23 & 0.1 & $20.8 \pm 0.21^{\mathrm{a}}$ & $0.45 \pm 0.21^{\mathrm{b}}$ & $0.1957 \pm 0.00^{b}$ \\
\hline $\begin{array}{l}\text { Incubation } \\
\text { Time (day) }\end{array}$ & $\mathbf{n}^{0} \mathrm{Cys}$ & wt of tissue & Protein (mg/l) & nmol Cys ${ }^{\mathrm{MT}}$ & nmol MT $g^{-1}$ \\
\hline 0 & 23 & 0.1 & $8.2 \pm 0.10^{\mathrm{d}}$ & $0.44 \pm 0.10^{\mathrm{d}}$ & $0.1913 \pm 0.00^{\mathrm{d}}$ \\
\hline 4 & 23 & 0.1 & $10.5 \pm 0.0^{c}$ & $5.57 \pm 0.00^{c}$ & $2.4217 \pm 1.26^{\mathrm{c}}$ \\
\hline 8 & 23 & 0.1 & $15.7 \pm 0.10^{b}$ & $9.89 \pm 0.10^{\mathrm{a}}$ & $4.3000 \pm 0.00^{\mathrm{a}}$ \\
\hline 16 & 23 & 0.1 & $25.4 \pm 0.26^{\mathrm{a}}$ & $7.29 \pm 0.26^{\mathrm{b}}$ & $3.1710 \pm 0.00^{\mathrm{b}}$ \\
\hline $\begin{array}{l}\text { Incubation } \\
\text { Time (day) }\end{array}$ & $n^{0}$ Cys & wt of tissue & Protein (mg/l) & nmol Cys ${ }^{\mathrm{MT}}$ & nmol MT $g^{-1}$ \\
\hline 0 & 23 & 0.1 & $8.2 \pm 0.10^{\mathrm{d}}$ & $0.44 \pm 0.10^{\mathrm{d}}$ & $0.1913 \pm 0.00^{\mathrm{d}}$ \\
\hline 4 & 23 & 0.1 & $11.3 \pm 0.10^{\mathrm{c}}$ & $6.4 \pm 0.10^{c}$ & $2.7826 \pm 0.01^{\mathrm{c}}$ \\
\hline 8 & 23 & 0.1 & $16.2 \pm 0.20^{\mathrm{b}}$ & $8.6 \pm 0.20^{\mathrm{b}}$ & $3.7391 \pm 0.02^{b}$ \\
\hline 16 & 23 & 0.1 & $25.5 \pm 0.00^{\mathrm{a}}$ & $8.9 \pm 0.00^{\mathrm{a}}$ & $3.8696 \pm 0.01^{\mathrm{a}}$ \\
\hline Protein (mg/l) & $\mathbf{n}^{0}$ Cys & wt of tissue & Protein (mg/l) & nmol Cys ${ }^{\mathrm{MT}}$ & nmol MT $\mathrm{g}^{-1}$ \\
\hline 0 & 23 & 0.1 & $7.3 \pm 0.00^{\mathrm{d}}$ & $0.41 \pm 0.00^{\mathrm{a}}$ & $0.1783 \pm 0.00^{\mathrm{a}}$ \\
\hline 4 & 23 & 0.1 & $8.4 \pm 0.20^{c}$ & $0.41 \pm 0.20^{\mathrm{a}}$ & $0.1783 \pm 0.00^{\mathrm{a}}$ \\
\hline 8 & 23 & 0.1 & $10.2 \pm 0.10^{b}$ & $0.4 \pm 0.10^{\mathrm{a}}$ & $0.1739 \pm 0.00^{\mathrm{a}}$ \\
\hline 16 & 23 & 0.1 & $18.9 \pm 0.26^{\mathrm{a}}$ & $0.4 \pm 0.26^{\mathrm{a}}$ & $0.1739 \pm 0.00^{\mathrm{a}}$ \\
\hline $\begin{array}{l}\text { Incubation } \\
\text { Time (day) }\end{array}$ & $\mathbf{n}^{0} \mathrm{Cys}$ & wt of tissue & Protein (mg/l) & nmol Cys ${ }^{\mathrm{MT}}$ & nmol MT $\mathrm{g}^{-1}$ \\
\hline 0 & 23 & 0.1 & $7.3 \pm 0.00^{\mathrm{d}}$ & $0.41 \pm 0.00^{\mathrm{d}}$ & $0.1783 \pm 0.00^{\mathrm{d}}$ \\
\hline 4 & 23 & 0.1 & $9.5 \pm 0.00^{c}$ & $5.8 \pm 0.00^{c}$ & $2.5217 \pm 0.00^{\mathrm{c}}$ \\
\hline 8 & 23 & 0.1 & $12.4 \pm 0.17^{\mathrm{b}}$ & $8.4 \pm 0.17^{\mathrm{a}}$ & $3.6522 \pm 0.00^{\mathrm{a}}$ \\
\hline 16 & 23 & 0.1 & $20.6 \pm 0.26^{\mathrm{a}}$ & $7.2 \pm 0.26^{\mathrm{b}}$ & $3.1304 \pm 0.01^{\mathrm{b}}$ \\
\hline $\begin{array}{l}\text { Incubation } \\
\text { Time (day) }\end{array}$ & $\mathbf{n}^{0} \mathrm{Cys}$ & wt of tissue & Protein (mg/l) & nmol Cys ${ }^{\mathrm{MT}}$ & nmol MT $\mathrm{g}^{-1}$ \\
\hline 0 & 23 & 0.1 & $7.3 \pm 0.00^{\mathrm{d}}$ & $0.41 \pm 0.00^{\mathrm{d}}$ & $0.1783 \pm 0.00^{\mathrm{d}}$ \\
\hline 4 & 23 & 0.1 & $9.3 \pm 0.10^{\mathrm{c}}$ & $5.24 \pm 0.10^{\mathrm{c}}$ & $2.2783 \pm 0.02^{c}$ \\
\hline 8 & 23 & 0.1 & $10.4 \pm 0.10^{\mathrm{b}}$ & $6.8 \pm 0.10^{\mathrm{b}}$ & $2.9565 \pm 0.01^{\mathrm{b}}$ \\
\hline 16 & 23 & 0.1 & $14.6 \pm 0.0^{\mathrm{a}}$ & $7.5 \pm 0.00^{\mathrm{a}}$ & $3.2609 \pm 0.01^{\mathrm{a}}$ \\
\hline
\end{tabular}




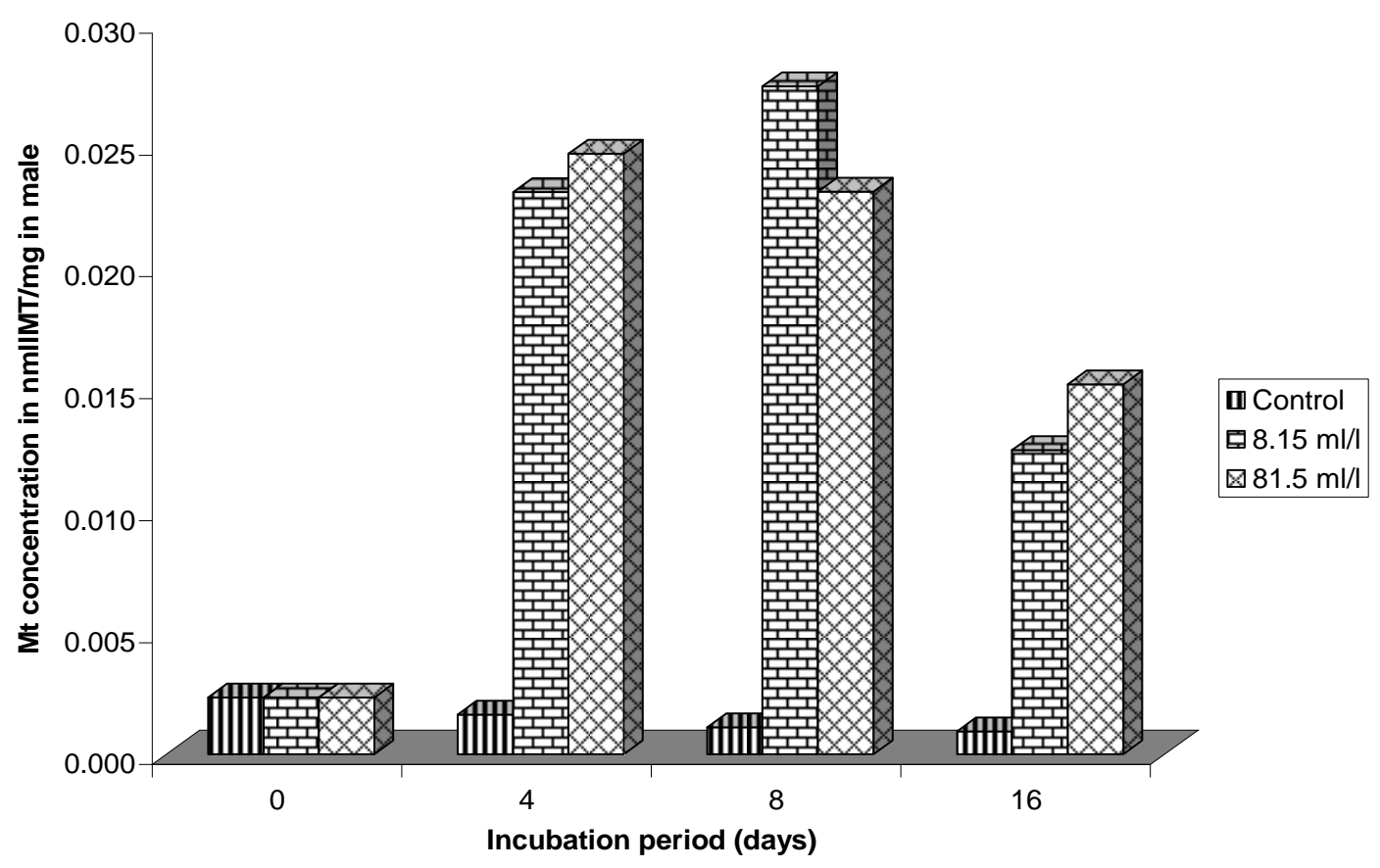

Figure 1: Varying levels of metallothionein as fraction of total protein in male S. huzardi.

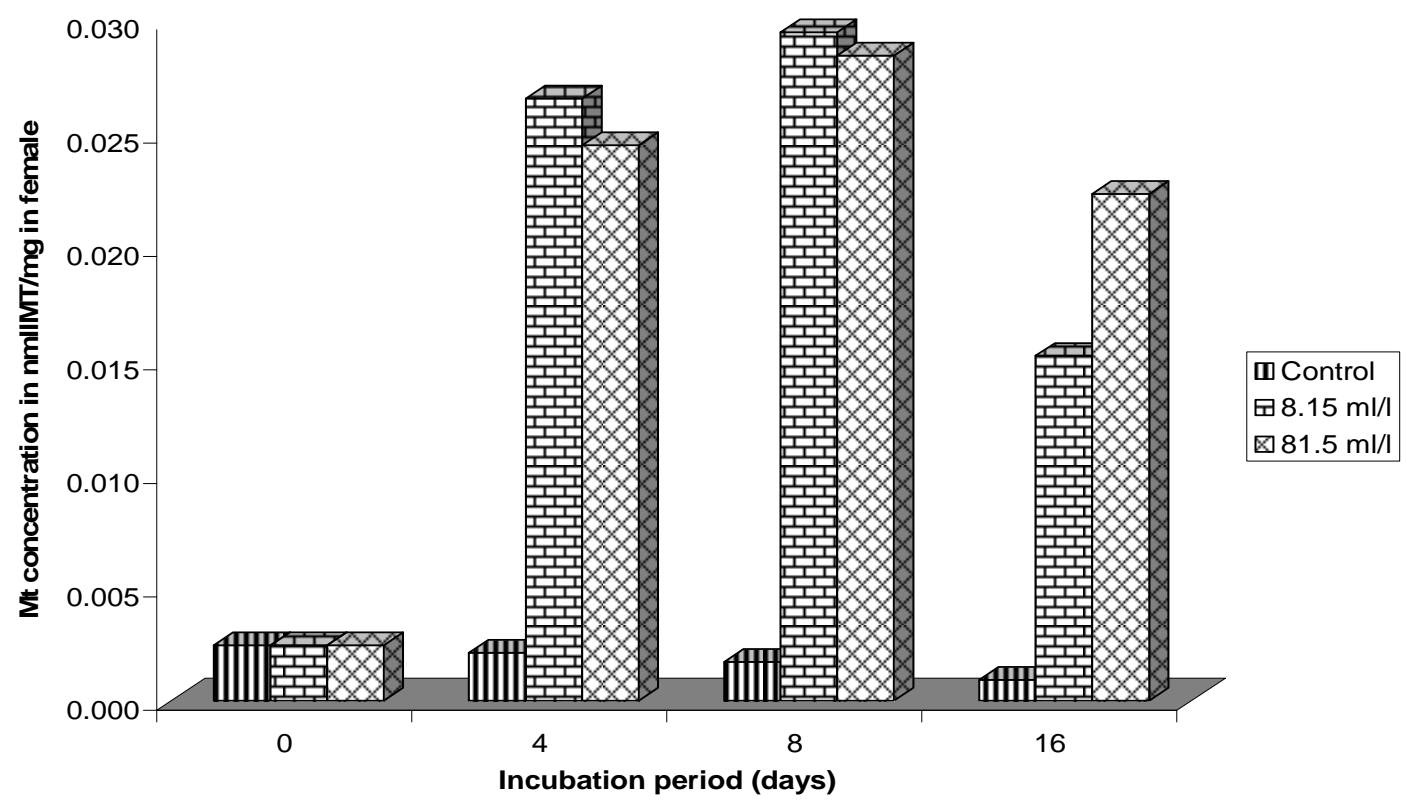

Figure 2: Varying levels of metallothionein as fraction of total protein in female S. huzardi. 
experimental chamber presupposes additional source of heavy metals which the crab will try to regulate if bioavailable for normal physiological functions. Metallothionein has been known to be induced by low levels of metal concentrations $(0.08 \mathrm{mg} / \mathrm{l} \mathrm{Cu}, 0.02 \mathrm{mg} / \mathrm{l}$ $\mathrm{Cd}, 0.6 \mathrm{mg} / \mathrm{l} \mathrm{Zn}$ in water (Domouhtsidou et al., 2004)). The increased induction of metallothionein represents a diversion of energy contingent to enable the organisms to survive under the new environmental conditions. Such reallocation of energy can lead to a reduction in growth, which in turn can result in delayed maturity or a decline in reproductive output (Calow, 1991). On the other hand, the variation in MT observed in drill cuttings exposed crabs could also be attributable to other components of the test chemical as drill cuttings is a composite toxicant. The authors are not aware of any previous study on induction of MT in animals exposed to drill cuttings. So it is difficult to compare results with that of other workers. However the results obtained were similar to the ones obtained for Tympanotonus fuscatus, a gastropod species but different from the results for Pachymelania aurita another gastropod species in another study carried out by the authors (Anagboso et al., 2010).

We were able to demonstrate the presence of MT in $S$. huzardi as well as show that exposure to drill cuttings have significant effect on the induction of the protein in this species thus suggesting the possibility of including metallothionein studies in biomonitoring programmes of drill cutting impacted marine areas as well as marine areas exposed to chronic levels of environmental pollutants. Adoption in this regard will of necessity demand further studies in factors affecting induction of MT, the characterisation and quantification of the different isoforms of MT that may be present in the crab as well as field studies to determine the influence of environmental variables on the induction pattern of the protein.

\section{REFERENCES}

Adams SM, Ham KD, LeHew RF. 1998. A framework for evaluating organisms responses to multiple stressors: mechanisms of effect and importance of modifying ecological factors. In Multiple Stresses in Ecosystems, Cech JJ, Wilson BW, Crosby DG (eds). CRC Press: Boca Raton Florida; 13-22.

Anagboso MU, Chukwu LO, Otitoloju A, Igwo-Ezikpe M. (2010). Metallothionein induction in edible mangrove periwinkles, Tympanotonus fuscatus var radula and Pachymelania aurita exposed to Oily Drill Cuttings. Journal of American Science, 6(2): 89-97.

Calow P. 1991. Physiological costs of combating chemical toxicants: ecological implication. Comparative Biochemistry and Physiology, 100(C): 3-6.

Calow P. 1995. Methods to assess the effects of chemicals on fresh waters. In Methods to Assess the Effects of Chemicals on Ecosystems, Linthurst RS, Bourdeau P, Tardiff RG (eds). John Wiley \& Sons: Chichester, UK; 436.

Damiens G, His E, Gnassia-Barelli M, Quiniou F, Roméo M. 2004. Evaluation of biomarkers in oyster larvae in natural and polluted conditions. Comparative Biochemistry and Physiology, 138 (Part C): 121-128.

Depledge MH, Hopkins SP. 1995. Methods to assess the effects on brackish, estuarine and near-coastal water organism. In Methods to Assess the Effects of Chemicals on Ecosystems, Linthurst RS, Bourdeau P, Tardiff RG (eds). John Wiley \& Sons: Chichester, UK; 125-149.

Domouhtsidou GP, Dailianis S, Kaloyianni M, Dimitriadis VK. 2004. Lysosomal membrane stability and metallothionein content in Mytilus galloprovincialis (L), as biomarkers combinations with trace metals concentrations. Marine Pollution Bulletin, 48: 572-586.

Ellman GL. 1959. Tissue sulfhydryl groups. Archives of Biochemistry and Biophysics, 82: 70-77.

English TE, Storey KB. 2003. Freezing and anoxia stresses induce expression of metallothionein in the foot muscles and 
hepatopancreas of the marine gastropod Littorina littorea. The Journal of Experimental Biology, 206: 2517-2524.

Galloway TS, Sanger RC, Smith KI, Fillman G, Readman JW, Ford TE, Depledge MH. 2002. Rapid assessment of marine pollution using multiple biomarkers and chemical immunoassays. Environmental Science Technology, 36: 2219-2226.

Ghoshal K, Wang Y, Sheridan JF, Jacob ST. 1998. Metallothionein induction in response to restraint stress transcriptional control, adaptation to stress, and role of glucocorticoid. J. Biol Chem., 273(43): 27904-27910.

Hamer DH. 1986. Metallothionein. Annual Review Biochemistry, 55: 93-95.

Handy RD, Depledge MH. 1999. Physiological responses: their measurement and use as environmental biomarkers in ecotoxicology. Ecotoxicology, 8: 329-349.

Handy RD, Galloway TS, Depledge MH. 2003. A proposal for the use of biomarkers for the assessment of chronic pollution and in regulatory toxicology. Ecotoxicology, 12: 331-343.

Klaassen CD, Liu J. 1998. Induction of metallothionein as an adaptive mechanism affecting the magnitude and progression of toxicological injury. Environmental Health Perspectivesss, 106 (Suppl 1).

Lacorn M, Lahrssen A, Rotzoll N, Simat TJ, Steinhart H. 2001. Quantification of metallothionein isoforms in fish liver and its implications for biomonitoring. Environmental Toxicology and Chemistry 20(1): 140-145.

Langston WJ, Bebianno MJ, Mingjiang $\mathrm{Z}$. 1989. A comparison of metal-binding proteins and cadmium in the marine molluscs Littorina littorea (gastropod), Mytilus edulis and Macoma balthica (bivalvia). Marine Environmental Research, 28: 195-200.
Leung KMY, Morgan IJ, Wu RSS, Lau JS, Furness RW. 2001. Growth rate as a factor confounding the use of the dogwhelk Nucella lapillus as biomonitor of heavy metal contamination. Marine Ecology Progress Series, 221: 145-159.

Moore MN, Depledge MH, Readman JW, Leonard DRP. 2004. An integrated biomarker-based strategy for ecotoxicological evaluation of risk in environmental management. Mutation Research, 552: 247-268.

Neff JM, McKelvie S, Ayers RCJr. 2000. Environmental impacts of synthetic based drilling fluids. OCS Study MMS 2000064. Report prepared for MMS by Robert Ayers \& Associates, Inc. for US Dept of Interior, Minerals Management Service, Gulf of Mexico OCS Region, New Orleans, LA. 118 p.

Newton LC, McKenzie JD. 1998. Brittlestars, Biomarkers and Beryl: Assessing the Toxicity of Oil-Based Drill Cuttings Using Laboratory, Mesocosm and Field Studies. Chemistry and Ecology 15(1 3): $143-155$.

Ng TY-T, Wang W-X. 2004. Detoxification and effects of $\mathrm{Ag}, \mathrm{Cd}$, and $\mathrm{Zn}$ preexposure on metal uptake kinetics in the clam Ruditapes philippinarum. Marine Ecology Progress Series, 268: 161-172.

Perkins EJ. 1979. The need for sublethal studies. Philosophical Transactions of the Royal Society of London B., 286: 425442.

Pitt BR, Schwarz M, Woo ES, Yee E, Wasserloos K, Tran S, Weng W, Mannix RJ, Watkins SA, Tyurina YY, Tyurin VA, Kagan VE, Lazo JS. 1997. Overexpression of metallothionein decreases sensitivity of pulmonary endothelial cells to oxidant injury. The Am J Physiol (Lung Cell Mol Physio) 17: L856-L865.

Roddie B, Skadsheim A, Runciman D, Kjeilen G. 1999. UKOOA Drill cuttings initiative research and development programme 
project 1.2: cuttings pile toxicity. Final Report UK Offshore Association Ltd ERT 99/232.

Roesijadi G. 1992. Metallothioneins in metal regulation and toxicity in aquatic animals. Aquatic Toxicology, 22: 81-113.

Roesijadi G. 1994. Metallothionein induction as a measure of response to metal exposure in aquatic animals. Environmental Health Perspective 102(suppl. 12): 91-96.

Viarengo A, Burlando B, Cavaletto M, Marachi B, Ponzano E, Blasco J. 1999. Role of metallothionein against oxidative stress in the mussel Mytius galloprovincialis Am J Physiol (Regul Integr Comp Physiol) 277: R1612-R1619.

Viarengo A, Burlando B, Ceratto N, Panfoli I. 2000. Antioxidant role of metallothionein: a comparative overview. Cell Mol Biol, 46(2): 407-417.

Viarengo A, Ponzano E, Dondero F, Fabbri R. 1997. A simple spectrophotometric method fot metallothionein evaluation in marine organisms: an application to to Mediterranean and Antarctic milluscs. Marine Environental Research, 277: 6984. 